\title{
Transgenic potato tubers with overexpression of 14-3-3 protein in growing rat diets. 2 . Redox indices in blood and brain ${ }^{1}$
}

\author{
I. Kosieradzka ${ }^{1}$, E. Sawosz ${ }^{1}$, J. Skomial', ${ }^{1,2}$ J. Szopa ${ }^{3}$, \\ I. Dudkowska ${ }^{1}$ and B. Pastuszewska ${ }^{2}$
}

\author{
${ }^{1}$ Warsaw Agricultural University, \\ Department of Animal Nutrition and Feed Science \\ Ciszewskiego 8, 02-786 Warsaw, Poland \\ ${ }^{2}$ The Kielanowski Institute of Animal Physiology and Nutrition, Polish Academy of Sciences \\ 05-110 Jablonna, Poland \\ ${ }^{3}$ Wroctaw University, Institute of Biochemistry and Molecular Biology \\ Przybyszewskiego 63, 51-148 Wroctaw, Poland
}

\begin{abstract}
The influence of feeding a diet without potatoes and diets containing $30 \%$ of non-transgenic or transgenic potatoes with overexpression of P 14-3-3 protein on antioxidant enzymes in blood and oxidative degradation in brain was determined in growing rats. The increase of activity of superoxide dismutase in blood and the concentration of 8-oxo-2'deoxyguanosine in brain tissue was similar in animals fed on both potato diets, which indicates that it was not related to genetic modification of tuber composition. The statistically significant differences in the investigated parameters did not result from the changes in the composition of the genetically modified potatoes caused by transgenesis.
\end{abstract}

KEY WORDS: transgenic potato, rats, DNA damage, antioxidant status

\section{INTRODUCTION}

Incorporation transgenic plants into a diet may be associated with risks resulting from a change in the concentration of nutrients and biologically active substances. Feeding rats a diet containing potatoes with overexpression of 14-3-3 protein did not influence growth performance (Kosieradzka et al., 2004) but a response of immunological system (Winnicka et al., 2001) was found. The aim of the present

\footnotetext{
* Supported by the State Committee for Scientific Research, Grant No. 3P06Z00925

${ }^{1}$ Corresponding author: e-mail: kosieradzka@delta.sggw.waw.pl
} 
study was to examine the influence of feeding potatoes with overexpression of 14-3-3 protein on selected parameters of redox status including the product of oxidative DNA degradation in brain.

\section{MATERIAL AND METHODS}

The potato tubers of Solanum tuberosum L. cv. Desiree with increased synthesis of 14-3-3 protein (Żuk et al., 2003) were obtained as in Part 1 (Kosieradzka et al., 2005).

Two isoproteinous casein diets containing $30 \%$ of dehydrated transgenic or non-transgenic potatoes of the Desiree variety, and a control diet without potatoes, were given to growing rats for four weeks as described by Kosieradzka et al., 2005. At the end of the experiment the rats were fasted for $12 \mathrm{~h}$ and euthanized by ketamine overdose, blood was sampled immediately from the heart, and brains were removed and frozen $\left(-70^{\circ} \mathrm{C}\right)$.

8-oxo-2'-deoxyguanosine (8-oxo-dG) was determined in brain tissue using a Dionex HPLC with electrochemical (at $350 \mathrm{mV}$ ) and UV (at $254 \mathrm{~nm}$ ) detectors and a $250 \times 4.6 \mathrm{~mm}$ Supelcosil LC-18-S column ( $5 \mu \mathrm{m}$ grain) and presented as the number of 8 -oxy-dG molecules per $10^{6}$ of unmodified dG - $8 \mathrm{odG} / 10^{6} 2 \mathrm{dG}$ molecules (Foksiński at al., 2000). In blood serum, biochemical parameters: glucose, albumin, total protein, $\mathrm{Fe}$ and $\mathrm{Ca}$ were determined using a Vitros DT II apparatus (Johnson and Johnson, USA). The activity of antioxidant enzymes in erythrocytes, i.e. superoxide dismutase (SOD), glutathione peroxidase (GSHPx) and total antioxidant status in blood serum (TAS) using kits from Randox Laboratories Ltd., were determined. SOD and GSH-Px activity was expressed as units per gram or mg of haemoglobin $(\mathrm{U} / \mathrm{g} \mathrm{Hb})$. The results were subjected to statistical analysis by single-factor analysis of variance ANOVA and Duncan's range test, using the Statgraphic 4.1 Plus software package.

\section{RESULTS AND DISCUSSION}

Oxidative damage of DNA leads to the formation of 8-oxo-2'deoxyguanosine, an adduct that occurs in DNA and causes mutagenesis (Helbock et al., 1998; Foksiński et al., 2000). The brain is not highly enriched in antioxidant protective defenses (Floyd et al., 2002) and is much more prone to peroxidation than the liver, kidney or muscle. A statistically significant increase of the 8-oxo-dG concentration in the brain was found in rats fed both transgenic and non-transgenic potatoes, as compared with control animals fed a diet without potatoes (Table 1). This points to the effect of a compound not related to genetic modification but specific for potatoes. In earlier experiments, feeding potatoes with overexpression of 14-3-3 protein increased the activity of the 
oxidative burst of neutrophils in rats. Activation of phagocytic cells to release reactive oxygen species (ROS) and pro-oxidant cytokines may consequently lead to oxidative damage, including DNA oxidation. The prooxidative activity of potatoes found in the present study may result from their relatively high content of Fe ions (Sugihara et al., 1999) or from the presence of biologically active substances, e.g. glycoalkaloids (Friedman et al., 2003). A tendency towards a higher Fe blood concentration was found in rats fed potato diets (Table 1).

The superoxide dismutase activity in blood serum was also significantly increased in rats fed both types of potatoes (Table 1).

Table 1. Antioxidant enzyme activities, concentration of selected biochemical parameters in peripheral blood of rats, and concentration of 8-oxo-2'-deoxyguanosine in the brain tissue

\begin{tabular}{|c|c|c|c|c|c|}
\hline & \multirow{2}{*}{ Control } & \multicolumn{2}{|c|}{ Potato } & \multirow{2}{*}{ SEM } & \multirow{2}{*}{$\mathrm{P}$} \\
\hline & & non-transgenic & transgenic & & \\
\hline $\mathrm{SOD}^{1}, \mathrm{U} / \mathrm{mg} \mathrm{Hb}$ & $2.04^{\mathrm{A}}$ & $2.33^{\mathrm{B}}$ & $2.25^{\mathrm{B}}$ & 0.0905 & 0.0042 \\
\hline GSH-Px², U/g Hb & 242.12 & 262.4 & 247.56 & 5.4200 & 0.1620 \\
\hline $\mathrm{TAS}^{3}, \mathrm{mmol} / \mathrm{L}$ & 0.856 & 1.025 & 0.927 & 0.0420 & 0.4400 \\
\hline Glucose, $\mathrm{mmol} / \mathrm{L}$ & 9.31 & 9.43 & 10.02 & 0.4849 & 0.5571 \\
\hline Total protein, $\mathrm{g} / \mathrm{dL}$ & 59.5 & 59.0 & 57.0 & 1.8120 & 0.6001 \\
\hline Albumin, $g / L$ & 33.2 & 31.8 & 31.0 & 1.0770 & 0.3739 \\
\hline Globulin, g/L & 26.3 & 27.2 & 26.0 & 0.9626 & 0.6658 \\
\hline $\mathrm{Ca}, \mu \mathrm{mol} / \mathrm{L}$ & 2.56 & 2.58 & 2.53 & 0.0517 & 0.2500 \\
\hline $\mathrm{Fe}, \mu \mathrm{mol} / \mathrm{L}$ & 34.98 & 41.98 & 41.58 & 6.0633 & 0.6327 \\
\hline $\begin{array}{l}\text { 8-oxo-2' deoxyguanosine, } \\
\text { 8odG/10 } 20^{6} \mathrm{dG}\end{array}$ & $3.3641^{\mathrm{A}}$ & $6.1543^{\text {в }}$ & $6.8573^{\text {в }}$ & 0.2905 & 0.0001 \\
\hline
\end{tabular}

The increase of SOD may be attributed to antioxidative substances such as polyphenols or other compounds stimulating ROS formation. Polyphenols can induce enzymes neutralizing active carcinogens and can increase the antioxidant potential of the cell. Natural polyphenols in potato tubers may prevent oxidation of cell lipids and not show the protective effect on DNA.

None of the biochemical blood parameters was affected by the presence or type of potatoes in the diet (Table 1).

\section{CONCLUSIONS}

Feeding transgenic or non-transgenic potatoes affects the red-ox homeostasis of growing rats in a similar way. As compared with the control diet, potatoes increased both the antioxidant enzyme activity in blood and the concentration of the product of oxidative DNA degradation in brain. 


\section{REFERENCES}

Floyd R., Hensley K., 2002. Oxidative stress in brain aging implications for therapeutics of neurodegenerative diseases. Neurobiol. Aging 23, 795-807

Foksinski M., Kotzbach R., Szymanski W., Olinski R., 2000. The level of typical biomarker of oxidative stress 8-hydroxy-2_-deoxyguanosine is higher in uterine myomas than in control tissues and correlates with the size of the tumor. Free Radical Biol. Med. 29, 597-601

Friedman M., Henika P.,. Mackey B., 2003. Effect of feeding solanidine, solasodine and tomatidine to non-pregnant and pregnant mice. Food Chem. Toxicol. 41, 61-71

Helbock H., Beckman K., Shigenaga M., Walter P., Woodall A., Yeo H., Ames B., 1998. DNA oxidation matters: The HPLC-electrochemical detection assay of 8-oxo-deoxyguanosine and 8-oxo-guanine. Proc. Nat. Acad. Sci. USA 95, 288-293

Jackson A., Loeb L., 2001. The contribution of endogenous sources of DNA damage to the multiple mutations in cancer. Mutat. Res. 477, 7-21

Kosieradzka I., Sawosz E., Pastuszewska B., Żuk M., Szopa J., Bielecki W., 2004. Effect of feeding potato tubers modified by 14-3-3 protein overexpression on metabolism and health status of rats. J. Anim. Feed Sci. 13, 329-339

Kosieradzka I., Sawosz E., Skomiał J., Szopa J., 2005. Transgenic potato tubers with overexpression 14-3-3 protein in growing rats diet. 1. Hormonal activity and liver functional status. J. Anim. Feed Sci. 14, Suppl. 1, 545-548

Sugihara N., Arakawa T., Ohnishi M., Furuno K., 1999. Anti-and pro-oxidative effects of flavonoids on metal-induced lipid hydroperoxide-dependent lipid peroxidation in cultured hepatocytes loaded with alpha-linolenic acid. Free Radical Biol. Med. 27, 1313-1323

Winnicka A., Sawosz E., Kluciński W., Kosieradzka I., Szopa J., Malepszy S., Pastuszewska B., 2001. A note of effect of feeding genetically modified potatoes on selected indices of nonspecific resistance in rats. J. Anim. Feed Sci. 2, 13-19

Żuk M., Prescha A., Kępczyński J., Szopa J., 2003. ARF regulates metabolism and antioxidant capacity of transgenic potato tubers. J. Agr. Food Chem. 51, 288-294

\section{STRESZCZENIE}

\section{Transgeniczne ziemniaki z nadekspresją białka 14-3-3 w diecie rosnących szczurów. 2. Wskaźniki redox we krwi i mózgu}

Określono wpływ żywienia szczurów dietą nie zawierającą ziemniaków oraz dietami zawierającymi 30\% ziemniaków transgenicznych z nadekspresją białka 14-3-3 lub nietransgenicznych na stan antyoksydacyjny i oksydatywną degenerację DNA tkanki mózgowej. Stwierdzono zwiększoną aktywność dysmutazy ponadtlenkowej we krwi i koncentrację 8-oxo-2'deoxyguanozyny w tkance mózgowej szczurów otrzymujących obydwa rodzaje ziemniaków. Statystycznie istotne różnice w wartości ocenianych parametrów nie zależaly od zmian w składzie bulw ziemniaków genetycznie modyfikowanych wywołanych transgenezą 